\title{
The Relationship Between Preferences for Online Large-Classroom Learning Methods and Self-Directed Learning Readiness
}

\author{
Diani Puspa Wijaya ${ }^{1 *}$, Umatul Khoiriyah ${ }^{1}$
}

${ }^{1}$ Faculty of Medicine, Universitas Islam Indonesia

*Corresponding author's email: diani.puspa@uii.ac.id

\begin{abstract}
The Covid-19 era has an impact on teaching. The Faculty of Medicine of Universitas Islam Indonesia develops online classrooms with a number of learning strategies. Self-directed learning readiness is one of the factors related to the selection of learning strategies. This study aims to determine the relationship between SDLR and online learning strategy preferences.

Methodology This study aims to survey students' preferences for online learning in large classrooms and their reasons as well as to investigate the levels of self-directed learning readiness of the students. Furthermore, a crosstab analysis was carried out to observe the relationship between the self-directed learning readiness of the students and their online learning preferences.

Results Out of 132 students, 70 (53\%) chose to study using the flipped classroom, 47 (35.6\%) chose synchronous lectures, while $15(11.4 \%)$ chose to independently study the lecture materials shared online. A total of 115 students $(87,1 \%)$ had a high level of SDLR, and 17 students $(12,9 \%)$ had a moderate level of self-directed learning. There is no relationship between students' preferences for online learning methods and students' self-directed learning levels ( $p$-value $>0.05$ ). Conclusion and Recommendation: Self-directed learning does not correlate with choosing the forms of online learning. It is necessary to carry out a further exploration of which factors play a role in online learning selection by students.
\end{abstract}

Keywords: online learning, student preferences, SDLR.

\section{INTRODUCTION}

In early 2020, the COVID-19 infection spread across the world, prompting WHO to declare a pandemic condition. Further prevention of the spread of the infection encourages public policies to carry out physical distancing [1]. This policy also applies to Indonesia, causing the learning at the school and university levels to be subject to distance learning rules. The Faculty of Medicine of Universitas Islam Indonesia (FM UII) also follows this policy by shifting the learning process to online learning through online classrooms.
Online classrooms are part of online learning. Online learning itself is learning using the internet to convey learning information [2]. An online classroom is a didactic learning process that can be accessed via a digital platform through the internet network. There are several types of online classrooms, such as those based on lecturers and students' interaction, which can be synchronous online classrooms, asynchronous online classrooms, or blended classrooms. Some divide the types into asynchronous online classrooms and interactive synchronous webinars $[3,4]$.

A synchronized online classroom is a form of online learning that has been 
developed at the beginning of the trend. Lecturers and students simultaneously log on to the digital platform and interact directly using the internet. The advantage of this synchronous online class is that the learning process and knowledge transfer occur in realtime [4]. Lecturers can directly ask questions and receive answers from students. The disadvantage of this method is that it requires a strict time setting, which is not in accordance with the jargon brought by the basic principles of online learning, anytime and anywhere. Synchronous online classroom learning is known as webinars, and widely used with this method are webinars, virtual meetings, or web conferences [3,4]. The digital platforms that are commonly used today include Zoom and G-meet.

Asynchronous online classrooms provide a more flexible online learning environment. The asynchronous online classroom materials can be text-based, such as materials in the form of slides or articles. It can also be lecture recordings in the form of audio or video. Students can access the materials provided anytime and anywhere $[3,4]$.

The next form of online classroom is blended classrooms, which combine face-toface learning with online interactive learning. Furthermore, an online classroom known as a flipped classroom is developed, an active learning method that allows students to study lecture materials before face-to-face meetings, and when face-to-face meetings are held there is a discussion using the student-centered learning (SCL) method [3, 4].

With medical students, we expect them to have good lifelong learning skills, one of which is shown in self-directed learning readiness (SDLR). One of the abilities in SDLR is metacognition skills, the students' ability to have ownership and authority of self-learning, choose the appropriate learning strategy, and analyze their learning progress ability and the efficacy of the chosen learning strategy $[5,6]$.

During the pandemic, the learning at FM UII has been adjusted to the prevailing policies so that there is a shift in learning activities to become full online learning for both lectures in large classrooms and discussions in small group tutorials. This is a significant change because, in the previous period, learning was still mainly face-to-face. This shift in online learning for the lecturers and students is a new challenge and requires an immediate adjustment process [7]. Various forms of learning innovation are developed to enable online learning changes to provide an effective learning process. Students are expected to be able to adapt to this process through their SDLR ability. This study aims to analyze the effect of selfdirected learning readiness on the selection of online learning forms. We hypothesize the relationship between SDLR and the selection of online learning forms as a new learning strategy applied during the COVID-19 pandemic conditions in FM UII.

\section{METHODS}

\subsection{Sampling and participant procedures}

This research was conducted from October to December 2020. The subjects of this study were the first-year medical students from the undergraduate medical program at FM UII. An online questionnaire, which includes the Self-Directed Learning Readiness Scale (SDLRS) questionnaire and the preferred form of online large-classroom learning methods, was given at the end of the semester. They were encouraged to fill out the questionnaire, but their participation remained voluntary. The names and other personal information of study participants were protected. The Research Ethics Committee of FM UII approved this study, and students were notified of this research and signed a consent form. 


\subsection{Questionnaire}

The questionnaire used in this study was the SDLRS developed by Dr. Lucy $M$. Guglielmino to measure an individual's readiness to learn independently in terms of attitudes, skills, and characteristics [8]. The questionnaire was adopted by Zulharman et al. [9]. SDLR is categorized as high if the score is $\geq 132$, moderate if $84 \leq$ scores $<132$, and low if the score is $<84$. The questionnaire also asked students' choices about the methods of online large-classroom learning. The options included a flipped classroom, share video recorded lectures or slides, and synchronous meetings through Zoom meetings.

\subsection{Statistical analysis}

Descriptive statistics were calculated, and bivariate analysis was performed. A relationship analysis with crosstab was carried out to identify the effect of SDLRS on students' preferences regarding online learning in large classrooms. The level of statistical significance was at 0.05 .

\section{RESULTS}

The population of this research was the first-year medical students of FM UII, and data were taken in December 2020. A total of 132 students stated that they were willing to participate in this research and complete the questionnaire. The univariate analysis results found that there were only two SDLR level groups among FM UII first-year medical students in 2020, namely high and medium levels. Most of them, 115 of 132 subjects $(87.12 \%)$, had a high level of readiness in SDL (Table 1).

Table 1. SDLR score

\begin{tabular}{|l|l|l|}
\hline & $\mathrm{n}$ & $\%$ \\
\hline High SDLR & 115 & $87.12 \%$ \\
\hline Moderate SDLR & 17 & $12.87 \%$ \\
\hline
\end{tabular}

There were three choices of online largeclassroom methods, namely sharing lecture materials online in the form of video or lecture slides, virtual face-to-face directly through scheduled Zoom meetings (synchronous online classroom), and flipped classrooms. Students' preferences for the online learning methods in a large classroom were ordered from the most, flipped classroom, direct virtual face-to-face, to the least chosen, which was the provision of course materials via online only (Table 2 ).

Table 2. Students' preferences for the online large-classroom methods

\begin{tabular}{|l|l|l|}
\hline & $\mathrm{N}$ & $\%$ \\
\hline Sharing lecture materials & 14 & $10.61 \%$ \\
\hline $\begin{array}{l}\text { Synchronous online } \\
\text { classroom }\end{array}$ & 47 & $35.61 \%$ \\
\hline Flipped classroom & 70 & $53.03 \%$ \\
\hline
\end{tabular}

From the cross-tabulation, it was found that the online large-classroom method that students with high SDLR mostly chose was flipped classrooms, with 60 students
(45.55\%). Even among students with moderate SDLR, the mostly chosen online large-classroom method was flipped classrooms, with ten students $(7.6 \%)$. The 
bivariate analysis between the SDLR level and the preference for online large-classroom methods using Fisher's exact test resulted in a p-value of 0.932 . This means that there is no relationship between the SDLR level and the preference for online large-classroom learning methods (Table 3).

Table 3. Relationship analysis of SDLR and students' preference for online large-classroom methods

\begin{tabular}{|l|l|l|l|c|}
\hline & $\begin{array}{l}\text { Sharing } \\
\text { lecture } \\
\text { materials }\end{array}$ & $\begin{array}{l}\text { Synchronous } \\
\text { online } \\
\text { classroom }\end{array}$ & $\begin{array}{l}\text { Flipped } \\
\text { classroom }\end{array}$ & v value \\
\hline High SDLR & $14(10.6 \%)$ & $41(31.1 \%)$ & $60(45.5 \%)$ & $\begin{array}{l}>0.05 \\
(0.932)\end{array}$ \\
\hline $\begin{array}{l}\text { Moderate } \\
\text { SDLR }\end{array}$ & $1(0.8 \%)$ & $1(0.8 \%)$ & $10(7.6 \%)$ & \\
\hline
\end{tabular}

\section{DISCUSSION}

Self-directed learning (SDL) is essential for an adult learner. SDL is a learning process that runs when an individual can understand learning needs, learning objectives, learning resources, and learning strategies, and evaluate their learning outcomes. A scale developed by Guglielmino can measure this SDL, and this scale is known as the SelfDirected Learning Readiness Scale (SDLRS) $[8,9]$.

The research found that the SDLR of FM UII students in the 2020 period was good with most of the students (87.12\%) having a high SDLR level. This is in line with several studies which previously reported that firstyear medical faculty students have good SDLR levels $[6,10,11]$. One of the factors contributing to the high SDLR scores of firstyear medical students is that they have not experienced stress in learning. A study found that stress in medical studies can determine SDLR as students who experience stress will have a low level of SDLR [12]. Meanwhile, the load of learning in the early years has not really affected the students, likely resulting in a good level of SDLR among students in the first year.

The high SDLR level of students in the medical faculty is fundamental. A high level of SDLR is essential for finding the appropriate learning strategies and resources $[9,13,14]$. SDLR is a good predictor of students' acceptance of e-learning. students with a high level of SDLR are able to determine better learning strategies by choosing e-learning media that are suitable with their needs [15].

There are several forms of online classroom with different effectiveness and satisfaction levels. Students prefer synchronous web conferencing lectures over asynchronous lectures since they find it easier to understand the learning materials that are directly delivered online. Students can ask questions directly to the lecturer when they do not understand the materials and obtain direct answers. Meanwhile, in asynchronous lectures, students have to study the materials themselves and cannot directly ask the lecturer some questions [4]. This is similar to that found in the results of this study. Students with both high and moderate SDLR levels prefer face-to-face virtual lectures directly using Zoom meetings rather than independently accessing the course materials distributed online.

The learning method for large-classroom online lectures mostly chosen by the subjects with an excellent SDLR level in this study was flipped classroom. A flipped classroom is a form of active learning, in which students 
are required to actively access learning materials before the face-to-face class [15, 16]. In face-to-face learning, there is more emphasis on discussions between students and lecturers. This flipped classroom supports student-centered learning, which fits the student subjects of this study who have a good level of learning awareness. Students with a high SDLR level will choose learning strategies that they think are more effective $[4,13]$.

The high percentage of flipped classrooms as a preferred learning method is in line with other research previously conducted. More than $60 \%$ students prefer flipped classrooms to traditional classes, synchronous classrooms, and asynchronous classrooms. Students' satisfaction with learning flipped classroom can be influenced by the method which allows students to study the materials first and then be guided by the lecturer in a discussion forum to understand more deeply the materials that have to be mastered. This is in accordance with the concept from the initial development of flipped classroom. A flipped classroom reverses what is done in a traditional classroom, where the lecturer explains theoretical materials in synchronous or faceto-face activities and then assigns tasks to solve a problem by applying the theory given. Meanwhile, in a flipped classroom, theoretical materials are given for independent study before the face-to-face process, then during face-to-face meetings or synchronous meetings, the lecturer gives problems related to the application of the theories that have been previously studied to be discussed with the students. This encourages students to understand a topic more deeply so as to have better mastery of the materials $[4,14]$.

One of the factors that influence the selection of online learning methods is the year of study. Students in the early years are more adaptable to online learning [7]. This is in accordance with the findings in this study. The flipped classroom in large-classroom learning is an online learning method that has just been developed at FM UII. The subjects in this study were the first-year medical students who had just started studying at the medical faculty during this pandemic. In the previous learning period in high school, they learned more with conventional face-to-face learning methods. Then when entering college, they have to immediately face the fully online learning. They are required to be able to learn using such method $[7,11]$.

Both synchronous classroom and flipped classroom learning have the advantage of allowing a good interaction process between lecturers and students. In this study, students still preferred flipped classrooms. In synchronous classrooms, lecturers can interact directly with students. If there are things that need to be questioned, student can ask about them directly, and answers can also be obtained directly [4, 15]. However, dissatisfaction in learning with synchronous mode can be related to technological problems. In this synchronous classroom learning process, there are strict time limitations. When the learning process is running, both students and lecturers have to own good technology, especially an excellent network to support the internet connection. If there is a connection problem, it will be troublesome or disturbing for the access to the information conveyed [15].

Another factor that can influence the preference for online learning forms is readiness for online learning [16]. Readiness for online learning includes students' readiness, readiness of the support systems, and infrastructure [11, 17]. Students' readiness for facing online learning can be influenced by a number of factors, including internal factors such as gender, age, motivation, learning style, and self-efficacy. In this study, these factors have not been 
explored to provide a complete description of the factors influencing students' preferences for online learning methods in the medical faculty.

Educational institutions such as medical faculty need to determine students' preferences for online learning methods. Therefore, the faculty can develop a learning process that takes these preferences into account. Selecting learning media based on students' preferences will encourage them to be more motivated to learn [18].

\section{CONCLUSIONS}

SDLR is not associated with the preferences for the form of online learning. SDLR may not be the only factor affecting students' preferences for online largeclassroom learning methods. It is necessary to conduct further exploration of which factors play a role in the selection of online learning methods by students. It is also important to consider students' preferences when designing online learning methods.

\section{REFERENCES}

[1]. World Health Organization 2020.https://www.who.int/dg/speeches/ detail/who-director-general-s-openingremarks-at-the-media-briefing-oncovid-19\%2D\%2D-11-march-2020.

[2]. Tang B, Coret A, Qureshi A, Barron H, Ayala AP, Law M. Online lectures in undergraduate medical education: scoping review. JMIR medical education. 2018;4(1): e11.

[3]. Ellaway R, Masters K. AMEE Guide 32: e-Learning in medical education Part 1: Learning, teaching and assessment. Medical teacher. 2008 Jan 1;30(5):45573.

[4]. Skylar AA. A comparison of asynchronous online text-based lectures and synchronous interactive web conferencing lectures. Issues in Teacher education. 2009;18(2):69-84.

[5]. Murad MH, Coto-Yglesias F, Varkey P, Prokop LJ, Murad AL. The effectiveness of self-directed learning in health professions education: a systematic review. Medical education. 2010 Nov;44(11):105768.

[6]. Leatemia LD, Susilo AP, van Berkel $H$. Self-directed learning readiness of Asian students: Students perspective on a hybrid problem based learning curriculum. International journal of medical education. 2016; 7:385.

[7]. Amir LR, Tanti I, Maharani DA, Wimardhani YS, Julia V, Sulijaya B, Puspitawati R. Student perspective of classroom and distance learning during COVID-19 pandemic in the undergraduate dental study program Universitas Indonesia. BMC medical education. 2020 Dec;20(1):1-8.

[8]. Guglielmino LM. Development of the self-directed learning readiness scale (doctoral dissertation, University of Georgia). Diss Abstr Int. 1978; 38:6467.

[9]. Zulharman. Peran Self Directed Learning Readiness Pada Prestasi Belajar Mahasiswa Tahun Pertama Fakultas Kedokteran Universitas Riau. Yogyakarta. UGM [Thesis]. 2008.

[10]. Slater CE, Cusick A, Louie JC. Explaining variance in selfdirected learning readiness of first year students in health professional programs. BMC medical education. 2017 Dec;17(1):1-0.

[11]. Balamurugan S, Kumar H. Self-directed learning readiness (SDLR) among medical students: a questionnaire-based study from an Indian medical school. South East 
Asian J Med Educ. 2015 Dec 28;9(2):59-64.

[12]. Heo J, Han S. Effects of motivation, academic stress and age in predicting self-directed learning readiness (SDLR): Focused on online college students. Education and Information Technologies. 2018 Jan;23(1):61-71.

[13]. Adams D, Sumintono B, Mohamed A, Noor NS. E-learning readiness among students of diverse backgrounds in a leading Malaysian higher education institution. Malaysian Journal of Learning and Instruction. 2018 Dec 31;15(2):22756.

[14]. Eslaminejad T, Nakhaee N. Self-Directed Learning Readiness Factors in Physicians for Implementing E-Learning in the Continuing Medical Education Programs. E-learning-Engineering, On-Job Training and Interactive Teaching. 2012 Mar 14:39-46.

[15]. Khatib Zanjani N, Ajam AA, Badnava S. Determining the relationship between self-directed learning readiness and acceptance of e-learning and academic achievement of students. Iran Journal of Nursing. 2017 Jun;30(106):11-22.

[16]. Hew KF, Lo CK. Flipped classroom improves student learning in health professions education: a meta-analysis. BMC medical education. 2018 Dec;18(1):1-2.

[17]. Kunin M, Julliard KN, Rodriguez TE. Comparing face-toface, synchronous, and asynchronous learning: postgraduate dental resident preferences. Journal of dental education. 2014 Jun;78(6):856-866

[18]. Muthuprasad T, Aiswarya S, Aditya KS, Jha GK. Students' perception and preference for online education in India during COVID-19 pandemic. Social Sciences \& Humanities Open. 2021 Jan 1;3(1):100101. 